\title{
Groundowater Legislation
}

\author{
by \\ W. E. Code \\ Irrigation Engineer \\ Colorado A \& M Colloge
}

Ground water control measures, as with many other kinds of control over people and property, are both wanted and resisted according to how a person" 3 interests may be affected。 No one argues these days that ground water in any natural situation is inexhaustiblo. Furthor it has the attribute that the effect of use cannot be foretold, but must be tested by use. In other words, development of a groundwater basin must begin before a measure of Its capacity can be ascertalnedo The ownership of such water is a mattor of great public concern and its dotermination is a necoso sary part of leg1siation governing sts useo. Investments in land are often made because of the oceurrence of this resource.

In a situation wherain there is not onough water for ald, it is also understandabie that the inftial dovelopors would want some protoction for their invostmento Thoy would want to init development to prevoni uItimeto oxhaustion of the regource. It Is obvious that automatically thore wlll be two groups formed. ono for and ono againgt jegulatory logislation This confis.et has apperred in overy stato whore developmont has already reached a mature status. Tho fight betwen proponents and opponents usually bocomes bitter and prolonged. However, this may not bo the sltuation whore Eround wator dovelopment is still of small importanco.

Good ground water logislation should have the effect of cloars Ing up cortain polnts of law, take into account oconomic lmplice tions and roduco litigationo liftigation, of courso, can novor bo oliminated but powor vostod in administration tonds to tako caro of many sltuations whlch would othentse have to bo sottled by courts. With the incroasing demand for moxe wators not just in tho

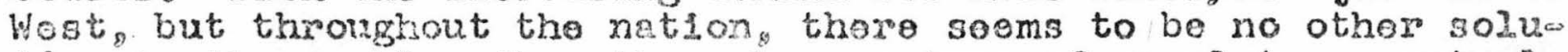
tion to the problem than through some type of regulatiory control.

A13. the 17 Wostem states have somo type of legialation

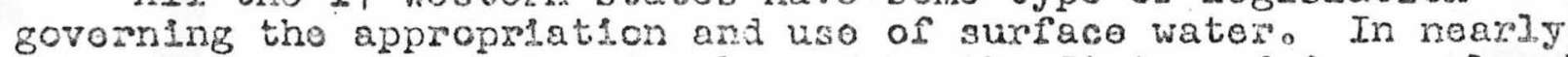
all instancos such water is clained by the stato and in noariy als lastances the priority systom prevalds. Tho Eastern statos are rearly all without spocisic hegistation and operate undor tho comon layo Juxisdation over wetor is oxereised through the police powarg of the etato. Homevor this gituation 13 charghing

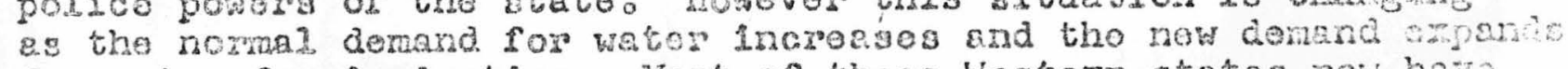

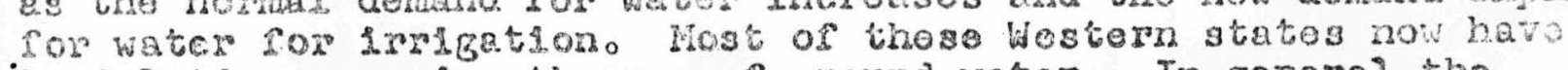
Iegislation covosing tho use of ground watoro In genorat tho 
systom adoptod for surface 1 low has been the one extended into the catogory of ground waters. Howovor, thore still remains vestiges of riparian rights for cortain classes of ground water in many states know by the legal fraternity as percolating waters.

Thore are two main philosophies of use of ground water. They are based on water ownership. One of these 1s the English or cominon law rulo which grants to the ownex of the overlying land the unqualified right to the use of the underlying ground water. Two varlations under this mile have beon devolopod in the Unitod Statos: the rule of roasonablo use and the rule of correlative rightso The socond 13 the doctrine of prefordty of appropriation or first in timo of use 1.s flirst in right of uso. Thoy are quite differont: one 13 prodicated on privato ownorship and the othor public ownorshipo

Let us examine first the English, comnon law, or riporian coctafio. As lndicatod, 2t stoms from theland and was naturaidy transportod to this country. It 1a not loglstation but tho rosult

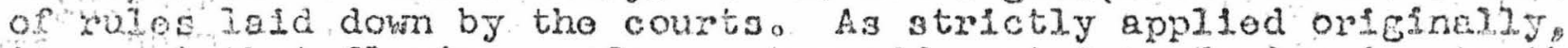
ft moent that flowing surieco vator adjaoent to and riparian to tho

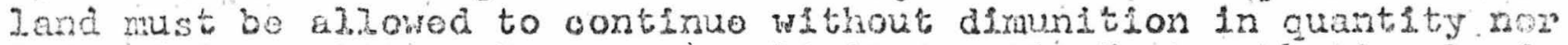

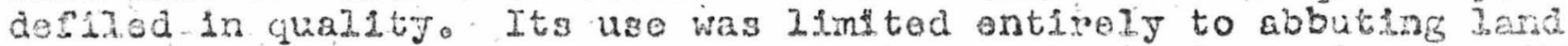

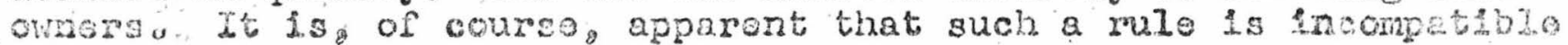

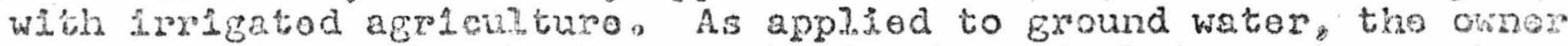
of the land has tho obsolute right to the underlying wataj as he

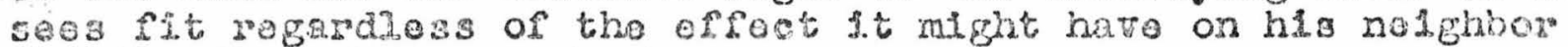
dranting from the same supply.

This was a very righd rule and as thme went on 1 to was seon to

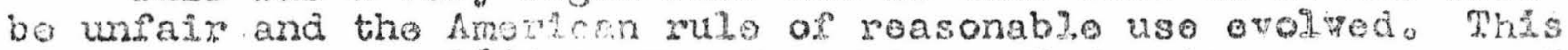

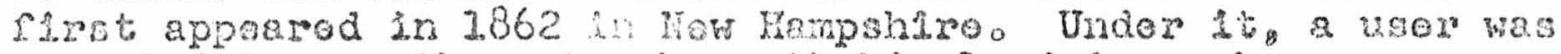
expoctod to use tho wato benseth hto land in such a munor as not to undviy injure the rights of anothoro Th1s ruto has boon applas Lis Colorado and in other wootom statos. It is difficule of fmberm protation in that the court must detormine what is reasoneble use. Eesh caso would havo to bo declded upon tho poculiar cincunstancos involvodo

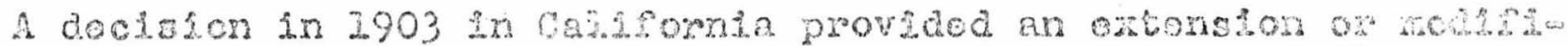

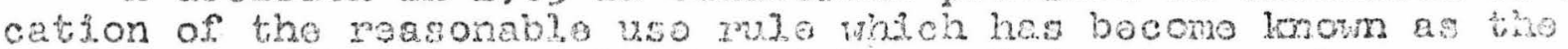

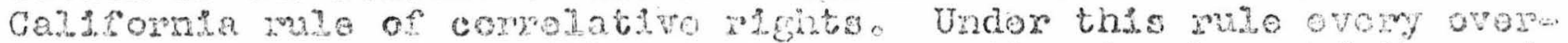

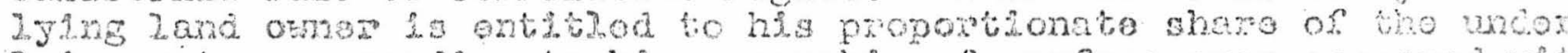

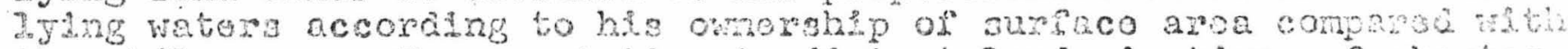
the rhoto arse. Trangportation to destrant lands in thros of ehortage

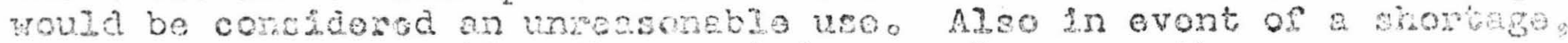
the courts may apportion the acmankng supply anong the usore.

At loesti 10 of the 27 weston statos havo edoptod tho

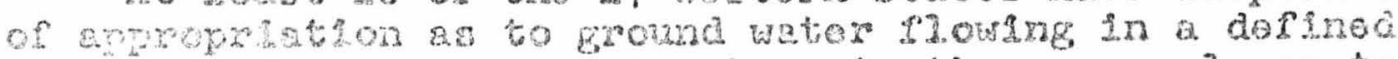

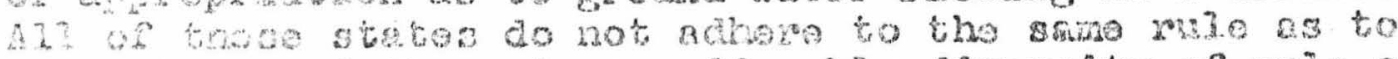

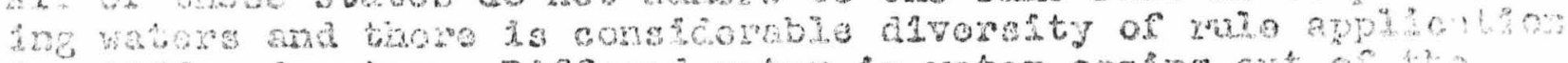

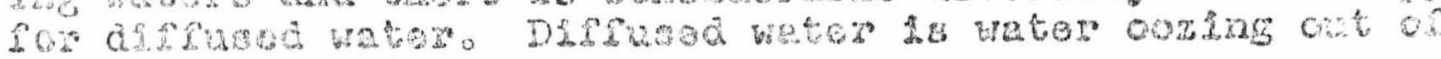


grourd as in bogs, marshes and sloughs not connected with stream channols. Those diatinctions botwoen varlous kinds of water aro those thought up by the legal fraternityo They do not make much sense to the groundewater hydrologist。

The appropriation doctrine noods little explanation to this audience. Its basic concoption 18 that of public ownership and its origin Iles in the consurnptivo use of water for irrigation. Although widely adopted in the West it rassic not be assumed that this systom 1s the ultimate, it has many doferts which we cannot go into. The system is sinilar in most respects as applied by the various states but various mothods may be usod to make appropriations. The idea of the first appropriator in point of time having the better right is tho same。 Bonoflcial use is the usual requirement as the limit of an appropriation, but it is often difficult of definition.

The operation of the prioilty system of appropriation as applied to ground wator is not as simple as to surface flows. Surface flows, of course, are visiblo and fairly accurate mothods of measuring them are avaliable. Not so with ground water. We have made tromen: dous strides in devoloping means of determining ground water flow characteriatics in the past 25 jears. However, there are so many Intanglbles involved that our moasurements yet are no bettor than intelifgent estimates. This uncortainty has resulted in skepticism on the part of many of the workability of ground water lawso This is particularly true in situations in which return flows are involved。

The doclaration of public ownership of surface water has noto with no serious opposition but not so with ground water. The common Jow and Homestead Act of 1862 convoys allsubsurisce rights to the land ownor. Although by dorinition water may bo considered a mineral. yot tho fact that ground wator may change suiface kater and vlce versa according to changos in topography and geology places It outside such a catogory as nom stij a bpILes to porcolating weter in many Westorn states where the appropriation doctrino has otherwise boen adoptodo Artesian water is genoraliz constared percoleting wator. Much confuston hes wesultod from this diviston into several kinds of watoro I might mention here that there is now in a Colorado court a case tosting whether 011. is a mineralo Reservation of minoral rights by a ralisoad. is involvodo

Let us $200 \mathrm{k}$ at how groundwater hegislation ls korking in 30 mo

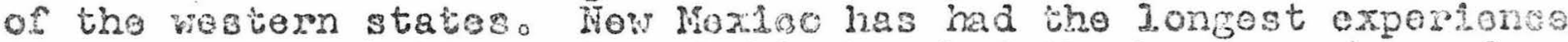
whth such Leglsdation and probably has had tho bost success of

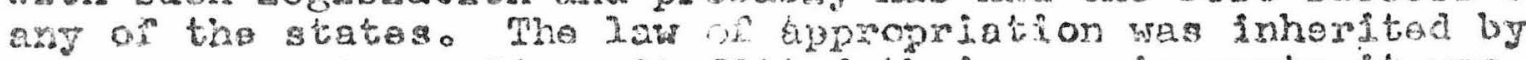

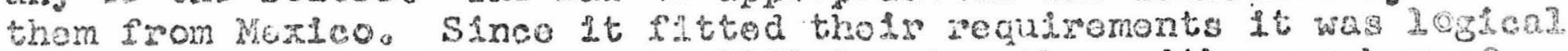
that they would adopt 1. Tho 2939 Inv togothor with a manber. of

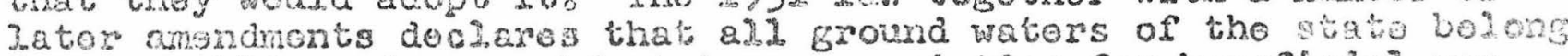

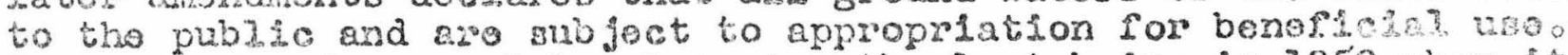
It has ondurod sororal legel. toets, tho last boing in 7950 when 1 t was again sustainod by the state Supromo Courto Tho Congrossionel. 
Dosort Land Act of 1877 comes into tho plcturo noro as to what was conveged with public land to a clalment. The Court hold that tho Act wag not I Imitod to suriaco wator and tho United Statos conveyod no intergs in wator that might bo urod for ixrlgationo The westorn states gonorally hold that they havo the right to administer waters of rononavigable gtroams within thelr boundaries. Rocont declsions of tho $U_{0} S_{0}$ Suprome Court soom to have invaded these rights and extended Federal control into the realm of ground water under Federal Tande?

Tho mothod of administration of ground wator use in Now Mexico (2) known as the poxint systemo It is generally consldered as tho bost under the prLor approprlation doctrine. The State Englnoer assurnes juridediction onjy over dosignated groundewater basinso Soomingly tho law dos not covor nor doos the Stato Englnoor have. any aluthority oter nonedosignatod aroaso Tho orfejnal jeglisiation rocognlzed oxlsting rights but usors woro requs rod to sfle declara

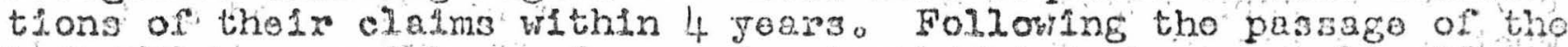

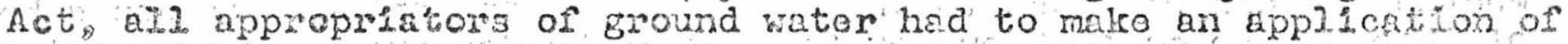
appropidation to the Stato thg noos. This application had to be

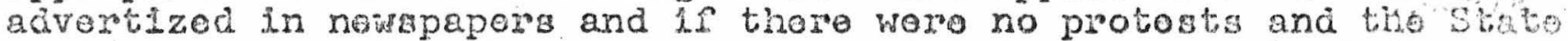

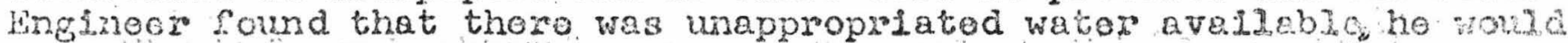
Lssue a permst to drill a vollo If not the epplication would bo donfedo So fas as I have boen able to discover the rulo of prionty has not boen involod by cutting of jumfor appiopriators zis an ovor doveloped area.

The gstuatson fin Lea County in the southeart comer of the

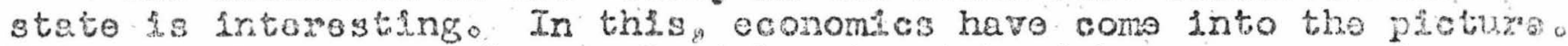
This aroe has a vory low replenfshment roto and honco any gexsoust 3ize of dovolopment rould mean withdrewn. of water from stonaseo

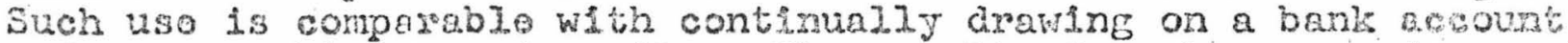
and nover makng any dopositio The rosult of such a procoduro of

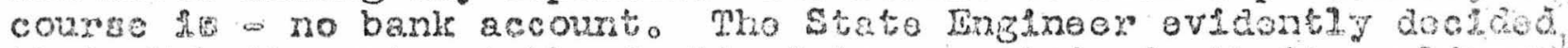

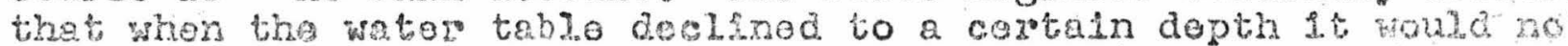
longez bo profittable to purpo In court testimony ho lnekcatod that about 40 jagrs coula bo consldered as a roeasonable life for a valor righto on some aush bass he closed tho basin to rurthor developmont in 2948. It is my uncorstandsing thet thxough cernto acton ise Strto Enginoer was roquired to reopen the aroa in 2952 but in suck a. manner thet the now wells woudd bo widaly spaeod.

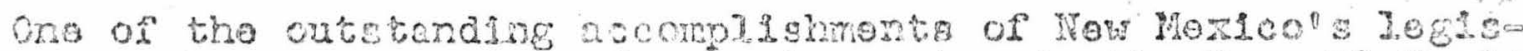

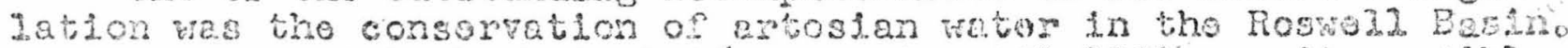

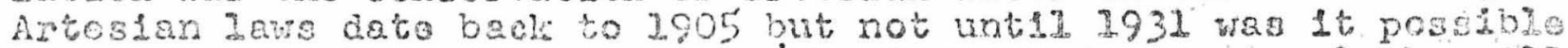

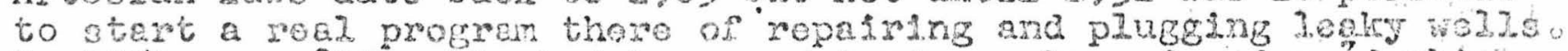

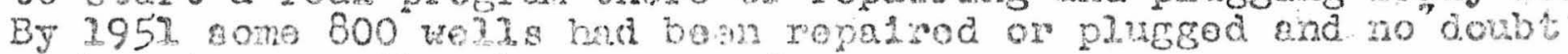
much vator was thoraby consurvedo

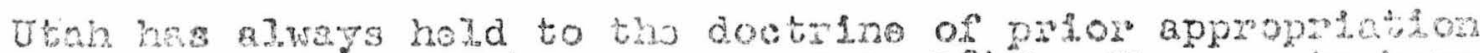

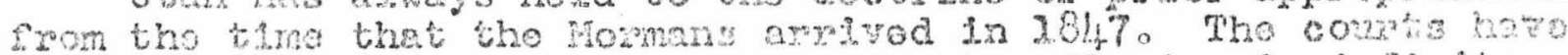

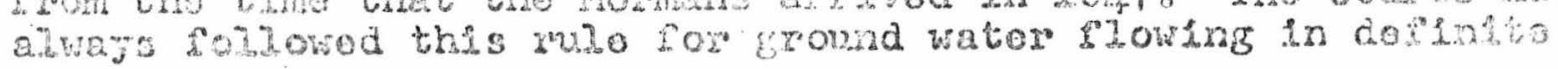


channel3o. As to porcolating wator undorlging lands in privato ownoro ship, howover, doclslons wore first based on absolute ownorship, then on tho rule of correlativo rights and lestly prior appropriationo Because of some court decialons in 1935, the year of the passage of thoir groundowater law, some uncertalnty as to its status exists according to an opinion volcod by Wells A. Hutching in 1940. Tho situation may bo changed as of now.

Rights to appropriato ground water are acquired by application to the state Englneer. On petition, or by his Initiation, the state Enginoer may make studies of ground water basins to determino the adoquacy of the supplyo Should he find that all the water has boen appropriated ho can dony the application. Such action, as is usual In all stato3, is roviowablo by tho courts. Undor certain circumstancos his report and recormendations are brought bofore a court and the rights doterminod. In casos of a finding by the state Engineer of an inadequate upply for existing clalms, he has the right to divide the supply among the clafmants. I am not informed as to whothor ho has rosortod to any such kind of rationingo It would bo of interest to me to know how this could be done under the priority system。

Comments of those ramiliar whth the functioning of the Utah law indicate that groundwator dovelopment has boen over conservative. It has not allowed fuld drvelopment of the resourceso In ono aroa, Cacho Valley, tho botton lands axo rostrictod in agricul turo bocause of lack of drainage. The golis overile an artesian aquifer and loak Qge through the conflning 501 Is causo a vot condition. Drainago is possible by rolfoving the artesian pressure by pumping, but that wovid Intexide with many flownB wol.1s and injunctions have prevented its omployments

The Fovada Act of 1939 and anended in 1949, docdares all grounc water belongs to the public and subjost to appropriation. It contafins something in the nature of a grandopather clauso in that thoso rights acquired for ground water in a deflnablo aquifor and artostan water prior to March 22, 1913 and rights to porcolating wator acquirod prior to liarch 25, 1939 wore considered vosted rightso A cleln had to bo fil 3 d by all appropriators subsoquent to thoso dator and the dato of priority was that whon the application was mado in propor form

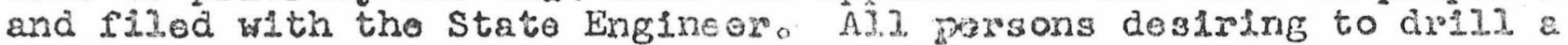
woll must firgt make appilcation and obtain a pormit from the stato Englnoero The State Enginoor may roatrict furthor drilling in a bas1. 25 ho finds: (1) that the gafo yiold has boon roached, (2) whon tho wator tabjo has been lowojod to appoint from which tho pumping lift approaches the maximum oconomical. Ilntt, or (3) whon fur ther dfrorsion will adversely affoct the economy of the aroa in generad, whlchover occurs slogt.

Tdaho $2 n$ fts statuto of 2951 and amondod in 2953 also doclaros alI ground water as belonghing to the stato. All rights acquirod

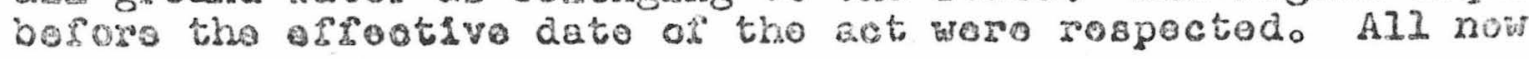


appropriations aro perfectod by application and pormit. Critical ground wator aroas may bo doslgnatod by tho Stato Roclamation Engiriero Should a porit bo roquosted from a critical area, the ract mist bo advortizod in the axea If a protest is ifled hoaro Ings mist bo hold in a proseribod mannor and if it found that thoro ng.s no surplia avalable, ho may deny tho applicationo Tho stato Roglamation Englnoer has diastio powors to Iimit withdrawals in. times of ghortageso The statuto rocognizos the possible offect of pumplag upon stioam flow and providos for the formation of tro kinds of wator d.stricts, one whore surface water could not bo affoctod and tho bther whero thon ves such a possiblisty A rathor complic

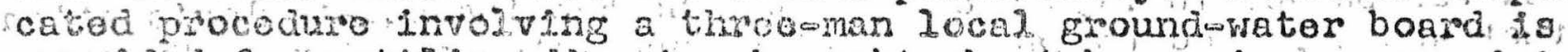
providod ror sottILng disputes brought about by somior appropmatorso

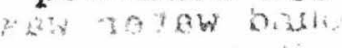

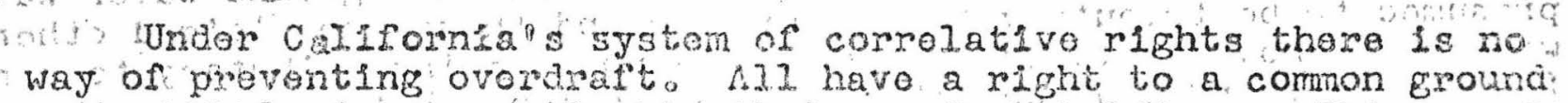

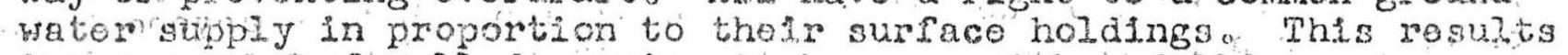
In a progiam of woll doopenting to koep up whth a rald ing waten table "Court rulanga goven tho aministration of tho suppis in

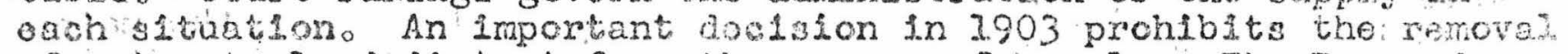
of water to land distant rrom tho soures of supplyo The Rajmono Basin caso in 1949, Pasacona vis Alnambia, is of groat jntorosti - Here the supply uas dotominod to bo 70 percent of the drat to phe Count consldered all right equivalent and docided on a streitht allocetion of the supply regardiess of tho type of uso and peimftred a uso of 70 percont of thedr actual provious uso. Further dovelop ment was prohibitedo Pasadena could and did eloct to use colorado Rlvor water instoad of ground water and whoudd any right holder use, more than 70 percont of his shroe ho would pey Pasadena for tho difîtenge

Arfuora hag had more wouble than axy other state in ltos strugghe to obtaln ground wator leglalation In 1948 after 3 or 4

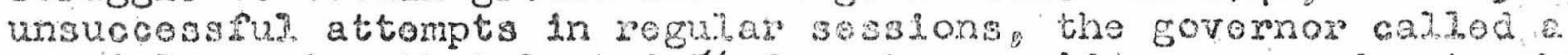

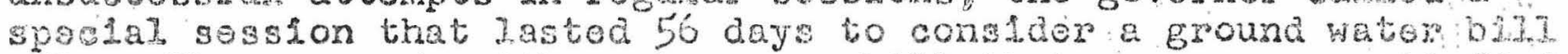

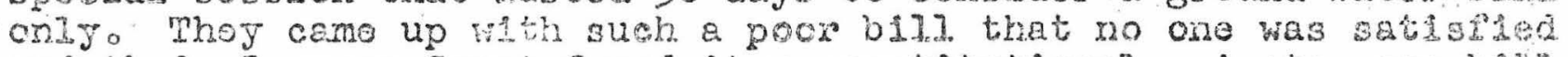
and thosp Supremo Cowit found it uneonstitutionalo A stop $82 p$ bith.

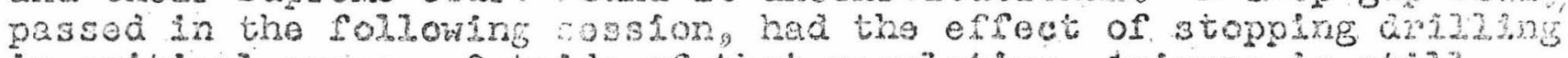

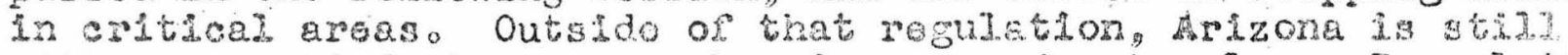

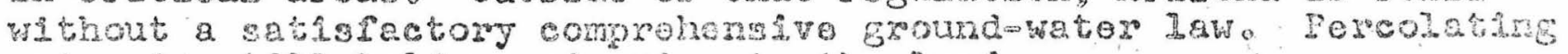

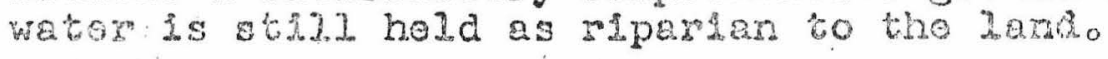

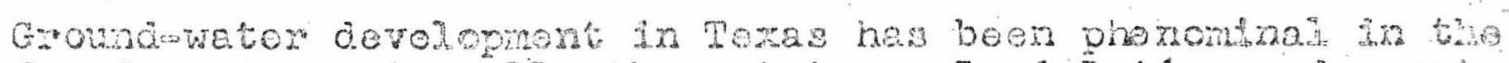

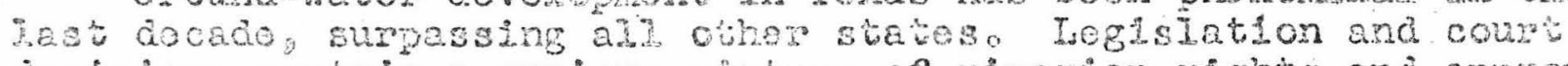

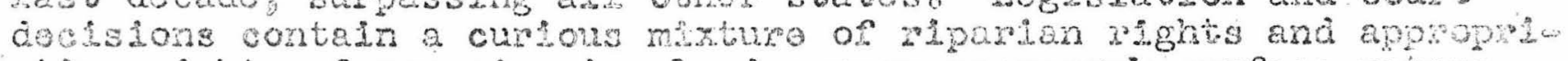

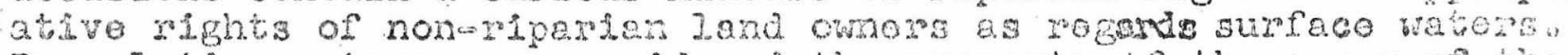
Pescolating wators axe constconod tho property of the mmox of bhe

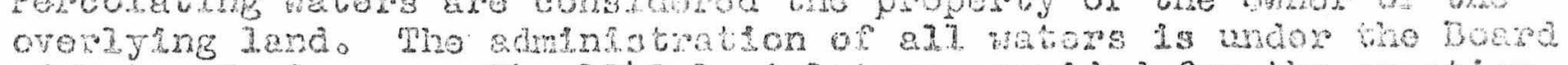

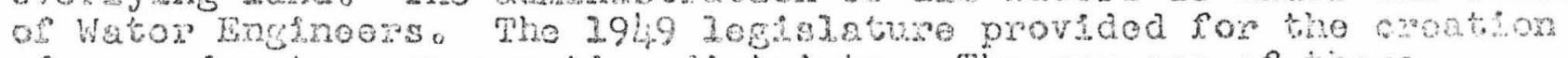

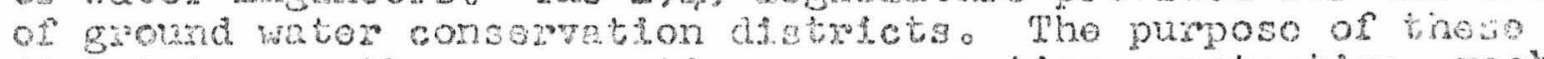

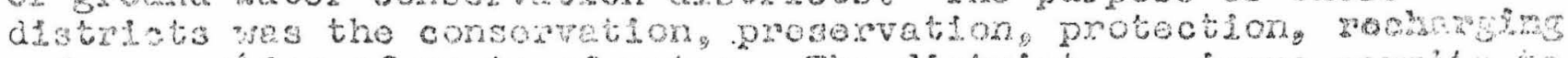

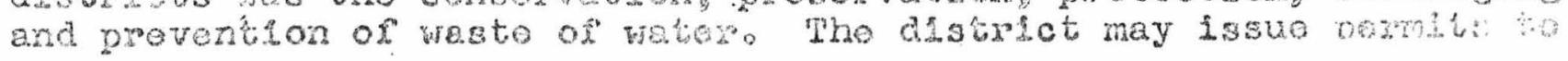


dr111 wel18 but no land owmor may be denled a permit to drillo No permit is neoded for a well producing less than 100,000 gallons per dayo The district can specify distances apart that wella may be drilled, In the High Plalns aroa, millions of new acres have been brought under 1rrigation from weldis." About 95 percent of the water is being drawn from 3torage. Since there can be no way of dimiting the draught under Texas laws, the water table will continue to be lowered. The present rate of lowering over a wide area is about 5 foet por yearo

Colorado has no ground-water law as such. A well construction law was passed in 1953 and to it was hooked inadequate legislation that was supposed to take care of ground water problems. Supreme court decisions bave firmly fixed the rule that all ground water was presumed to be tributary to stream flow and those who claimed othor wise must show conclusively that it is not. Being tributary to stream rlow it is therefore subject to appropriation. Before anyone thought of wells as a water supply, all surface water had been appropriated。 This means that any rights that might have been acquired in ground water would all be junior to surface rights. Here lies the main stumbling block in groundwwater legislation for Colorado. It is rather obvious that wells along the stream courses fed by ground water will intercopt to some extent such underflow. Surface rights are superior and no law would bo valid or acceptable that would materialay damago such rights。 All efforts in the past 5 years to produce an accoptable ground water bll.l have met with much opposition from many sourcos。

The Ideal approach to this situation, of course, would be for a state to be prepared with legislative statutes on ground wator before devolopment startod. But who evar heard of such a thing as legisiation to anticipate troubloo wo walt until it is upon us. As ground water comes into use, capttal linvestment can bocomo vory large 1ndeod. If wo may fignore conflict witid surface water users we have lest then only a conflict botween ground-water users, but an important decision has to be made. Should a water resource bo mined and prodico a boom and bust economy or shall it be used in such a manner as to produce a suatalned economy. From what I have told you, you can seo how some of the states are meeting the stivationo

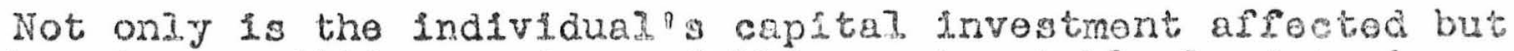

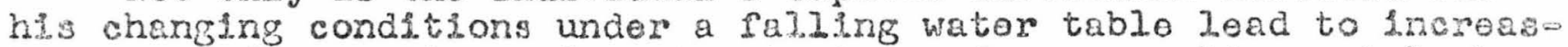
sing cost of operation. Investmonts in roada. power Ilnes telephono I nes and urban Intorpmizes all aro affoctedo One needs only to ponder the edty of Lubbcots. Texaso In 2940 1ts population was $32,000 \%$ in 3950 it was 71,700: and in January 3955 it was estimatod at 113,000 . A2I this growth was cavsed by the growth of agriculturo from 1mpigation - mainiy of cottono what of lts futuros

Whon wo introduce the added complscation of Interference whth stroam flow, troublas incroase. In Colorado there axo many pumping plants in the vallogs of stroens carrylng approprated watero those 
pumps are used mainly to supplement stream flow and are of great value to those holding lato prioritios and to ald in timos of low stream flow. Were these pumps nct operating, no doubt the volumo in the stream would be greatero Someone is being injured but it is very difficult to say who that someone is and how greatly he has boen linjuzedo These aquifers aro recharged annualdy through losses from irrigation. They congtitute a reservolin which can be filled up whon there are surpluses. The groatost benefleial use occurs whon such water can be mado avaliable at a critical time. Howevero there can be no doubt that property rights are being invaded in the processo

There seems to be no ono rulo that could bo called best for all situations. The priority systom, strictiy applied in underodoveloped territory vill doubtioss meet requiroments of proventing ovordrafto However, wholo an ovordraft has oceurrod, it would seem that the only reseus would be through cutting back uso in the reverse orcior or priorities. Under many conditions this would do the trick, but in Colocado wo have numerous situations whoro it would rasul.ti in unfadr hardshlps. Many aquifors occupy rathor narror and shalzon trough shapod valloys underlatn by shalo. Tho oldox prioritios mey bo locatod along the edges whore the wolls would be first afrected by a droppling water table. Thoy bould not like the priolity

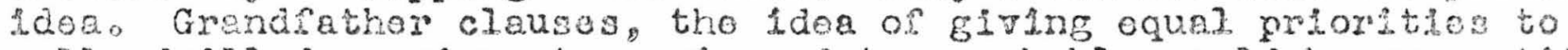
wolls dilliod provious to a glvan date, probably would be unconstitu tLonal. Rationing seoms 1mprobable, at least I lnow of no lnstences of its bolne employod. Its velidity would have to bo deciad by the courtso Wolns along stroms having prioxltises fundor to stroem

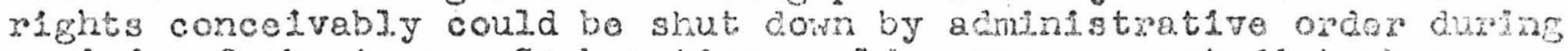
poziods of shortago. Such action would causo a great disturbenco

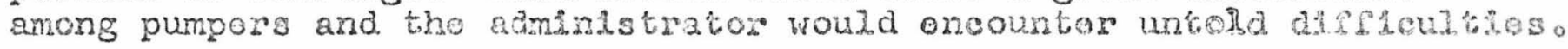

Calpromfa soems to have found a way undor lis corrolatwo phets true to curtall punping in a basin where overdraft has occurado Thls carno about through court action rather then legtis 2agicro Apperontly this wolld not be possible in lexaso

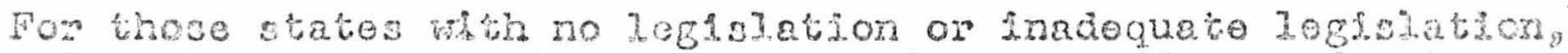
a solution that would provide for the maximum use of ground wataros

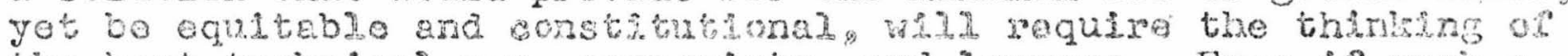

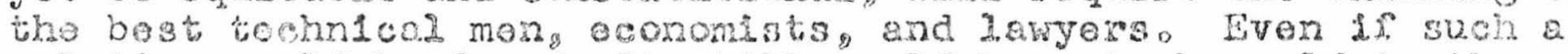
solution could be round, it still would have to be sold to tho logisiators through the people。 